Tropical Journal of Pharmaceutical Research April 2011; 10 (2): 187-193

(C) Pharmacotherapy Group,

Faculty of Pharmacy, University of Benin

Benin City, 300001 Nigeria.

All rights reserved.

Research Article

Available online at http://www.tjpr.org

\title{
Immunomodulatory Effect of the Aqueous Extract of Erigeron floribundus (Kunth) Sch Beep (Asteraceae) Leaf in Rabbits
}

\section{FA Yapo*1, FH Yapi ${ }^{1}$, H Ahiboh ${ }^{2}$, M-L Hauhouot-Attounbre ${ }^{2}$, NZ Guédé ${ }^{3}$, JA Djaman ${ }^{1-4}$ and D Monnet ${ }^{2}$}

Laboratoire de Pharmacodynamie-Biochimique, UFR Biosciences, 22 BP 582, ${ }^{2}$ Laboratoire Biochimie et biologie moléculaire, UFR Sciences Pharmaceutiques et Biologiques, BP V 34, ${ }^{3}$ Laboratoire de Botanique, UFR Biosciences, Université de Cocody-Abidjan, 22 BP 582 Abidjan 22, ${ }^{4}$ Département de Biochimie Médicale et Fondamentale Institut Pasteur de Cote d'Ivoire, 01 BP 490 Abidjan 01, Cote d'Ivoire

\begin{abstract}
Purpose: The leaves of Erigeron floribundus (Kunth) Sch. Beep. or (syn: Conyza sumatrensis (Retz) E.K. Walker) (Asteraceae) are used by some traditional healers in West Africa in HIV/AIDS therapy. The purpose of this study was to assess the immune-boosting properties of the aqueous leaf extract of Erigeron floribundus (Ef) by monitoring blood markers of cellular immunity in rabbit.

Methods: Two sets each of five groups (six rabbits per group) were used in this study. The groups in the first set each received intraperitoneally a single dose of $\mathrm{Ef}(25,50,75$ or $100 \mathrm{mg} / \mathrm{kg})$ or $0.9 \% \mathrm{NaCl}$ (control). The groups in the second set received methylprednisolone (15 mg/kg, MP15) and mixtures of MP15 with Ef (50, 75 or $100 \mathrm{mg} / \mathrm{kg}$ ), MP15 or isoprinosine $50 \mathrm{mg} / \mathrm{kg}$ (Ip50, reference standard). Whole blood was collected in EDTA tubes from the marginal vein of the rabbit ear on Days 0, 3, 9, 15 and 21 after administration for the determination of CD4+ count by flow cytometry, and also of neutrophils and total lymphocytes in the blood.

Results: Each plant extract dose tested (50, 75 and $100 \mathrm{mg} / \mathrm{kg}$ ) induced a significant increase in neutrophils $(p<0.001)$, total lymphocytes and TCD4+ $(p<0.0001)$ from the 3rd to 15th day after administration, compared to control $(0.9 \% \mathrm{NaCl})$. Furthermore, the same test extract doses significantly reversed the immunosuppressive effect of methylprednisolone $(p<0.001)$ to the same extent as isoprinosine.

Conclusion: The aqueous extract of the leaves of Erigeron floribundus stimulated the increase of neutrophils, total lymphocytes and TCD4+ in rabbit blood and thus provides some justification for its use in the traditional treatment of AIDS.
\end{abstract}

Keywords: Cellular immunity, CD4+ count, Isoprinosine, Erigeron floribundus, Methylprednisolone; Rabbit 


\section{INTRODUCTION}

It is well known that infections induce decrease in immune response through the inhibition of CD4+ and CD8+ cells [1]. The main cells affected by this immunosuppressive action are the lymphocytes and neutrophil. The neutrophils are known as dedicated phagocytic cells of the innate immune system. These cells represent up to $70 \%$ of the white blood cells of circulating blood. They are recruited to the sites of infections. There, they exert their phagocytic activity, destroying germs with reactive oxygen species and bactericidal proteins or other potent molecules. TCD4+ cells have a major role in the immune system, in which a decrease implies a weakened immune system due to infection [2]. Hence, decrease in the CD4+ count in some viral diseases, such as HIV [3], is an indication for antiretroviral (ARV) therapy [4]. In other pathological conditions such as cancer and autoimmune diseases, decrease in $T$ lymphocytes, predominantly CD4+ cells, indicates weakness of the immune system [5]. In contrast, in the case of organ transplants, immunosuppressive treatment with a glucocorticoid (such as methylprednisolone), cytotoxic drugs and antibodies are administered after transplanttation to prevent graft rejection [6].

Immunosuppressive diseases such as HIV/AIDS may require the addition of immunostimulator in combination with antiretrovirals (ARVs) on the one hand or as a monotherapy, on the other hand, to avoid taking ARVs. Indeed, ARV drugs have several side effects including skin reaction, fatigue, nausea, diarrhea, fever, insomnia [7] which can be stressful to patients. It is, therefore, necessary to strengthen the immune system by stimulating the production of CD4+ T lymphocytes.

In West Africa, the plant, Erigeron floribundus (Asteraceae), is used traditionally in AIDS therapy. In addition, Asongalem et al [8] have reported the peripheral and central analgesic properties as well as the anti-inflammatory activity of the aqueous extract of Erigeron floribundus. Tra $\mathrm{Bi}$ et al [9] has also demonstrated the antifungal activity of the dichloromethane extract of the plant extract.

The objective of this study was to evaluate the immunostimulatory property of the aqueous extract of Erigeron floribundus leaf.

\section{EXPERIMENTAL}

\section{Plant material}

The leaves of Conyza sumatrensis (Retz.) E. Walker Syn. Erigeron floribundus (Asteraceae) were collected from the tropical forest of southeastern part of Cote d'lvoire in January 2009. The plant material was identified and authenticated by $\operatorname{Pr}$ Laurent Ake-Assi of the Department of Botany, University of Cocody, Abidjan, Côte d'Ivoire. A voucher specimen (no. 5392) of the plant material was deposited in the herbarium of the National Floristique Center of the University of Cocody-Abidjan, Côte d'Ivoire.

\section{Preparation of aqueous extract}

The leaves were sorted, washed, dried at ambient temperature and then ground into fine powder. Two hundred grams $(200 \mathrm{~g})$ of this powder were macerated in $1 \mathrm{~L}$ of distilled water for $24 \mathrm{~h}$ and filtered, first through a soft fabric and Whatman filter paper No.1. The filtrate was dried in an oven at $50{ }^{\circ} \mathrm{C}$. The dry extract was dissolved in distilled water prior to animal tests.

\section{Animals}

Rabbits of the species Oryctolagus cuniculus, aged between 3 and 4 months and weighing $1.5 \pm 0.3 \mathrm{~kg}$ were used. They were provided by a breeding company and were acclimatized at $25^{\circ} \mathrm{C}$ in a $12 \mathrm{~h}$ light/12 $\mathrm{h}$ dark cycle in the pet room of the laboratory for 14 days prior to the experiment. The animals were given feed $\left(\mathrm{FACl}^{\circledR}\right.$ Company, Abidjan, Cote d'Ivoire) for rabbits and tap water $a d$ 
libitum. The equipment, including handling and sacrificing of the animals were in accordance with European Council Legislation $87 / 609 /$ EEC for the protection of experimental animals [10].

\section{Chemicals}

The immunosuppressive agent used was methylprednisolone sodium succinate (SoluMedrol $^{\circledR}$, Pharmacia Laboratories ${ }^{\circledR}$, France). As for the immune reference, we used the Isoprinosine (Sanofi-Aventis, France).

\section{Immunomodulatory test}

To determine the effect of the plant extract on total lymphocyte, CD4+ and neutrophils, two types of experiments were performed with two sets of 5 groups of 6 rabbits each. The first set received intraperitoneally a single dose of the extract $(25,50,75$ or $100 \mathrm{mg} / \mathrm{kg})$ for groups $1 \mathrm{a}-4 \mathrm{a}$, and $0.9 \% \mathrm{NaCl}$ for group $5 \mathrm{a}$ (control). The second set received intraperitoneally methyprednisolone (15mg/ $\mathrm{kg}, \mathrm{MP15}$ ) alone (group 1b) or MP15 plus the extract $(50,75$ or $100 \mathrm{mg} / \mathrm{kg})$ for groups $2 \mathrm{~b}-$ $4 \mathrm{~b}$, and MP15 plus isoprinosine $(50 \mathrm{mg} / \mathrm{kg}$, Ip50) for group 5b [11]. In each case, a blood sample was taken from the marginal vein of the rabbit ear on the first day (D0) before the injection of the drugs/extract, and then weekly for 3 weeks, and kept in EDTA tubes to prevent blood coagulation. The blood was used the same day for the determination of total lymphocytes, CD4+ T-lymphocytes and neutrophils. Prior to each sampling, the animals were weighed on a balance (Ametek Chatillon $^{\circledR}$, USA).

\section{Determination of lymphocytes, neutrophils and TCD4+ lymphocytes}

Total lymphocyte count and neutrophil blood count was carried out on a portion of the whole blood using a hemogram (Sysmex XT$2000 i^{\circledR}$, Framingham, USA). The other portion of whole blood was used to determine the level of CD4+ $T$ lymphocytes by the method of Becton Dickinson (BD) Tritest (CD3 PerCP
FITC/CD4 PE/CD45) with a flow cytometer (BD FACS Calibur ${ }^{\circledR}$, (New Jersey, USA).

\section{Statistical analysis}

Statistic analysis was undertaken with GraphPad Prism V5.01 software (GraphPad, Washington, USA). Groups of data were compared by one-way analysis of variance (ANOVA). Due to the small population size, the non-parametric Dunnett test was performed to assess differences between the control group and the other groups. For the comparison of variance between the groups, we used the non-parametric test of KruskallWallis. Differences were considered statistically significant at $p<0.05$.

\section{RESULTS}

\section{Effect of the extract (Ef) on neutrophils}

Figure 1 showed that the injection of increasing doses of the extract (Ef) to the rabbits induced a significant increase in neutrophil count on Day 3 from $(1.49 \pm 0.29)$ $\times 10^{3}$ to $(2.22 \pm 0.17) \times 10^{3}$ cells $/ \mu l(p<$ $0.001)$ for Ef50, $(2.02 \pm 0.2) \times 10^{3} \mathrm{cells} / \mu \mathrm{l}(p<$ $0.05)$ for $E f 75$, and $(2.12 \pm 0.24) \times 10^{3} \mathrm{cells} / \mu \mathrm{l}$ $(p<0.001)$ for Ef100. However, on Day 9, neutrophil levels were $(1.49 \pm 0.29) \times 10^{3}$ to $(2.52 \pm 0.15) \times 10^{3}$ cells $/ \mu \mathrm{l}(p<0.001)$ and $(2.62 \pm 0.14) \times 10^{3}$ cells $/ \mu l(p<0.001)$ for Ef50 and Ef75, respectively.

\section{Effect of combined extract and methyl- prednisolone/isoprinosine on neutrophil count}

Figure 2 shows that while methylprednisolone (MP, 15mg/kg) alone had no effect on the count of neutrophils, combining it with the extract increased neutrophil count to as high as $(3.02 \pm 0.27) \times 10^{3}$ cells $/ \mu \mathrm{l}(p<0.001)$ on Day $9,(2.50 \pm 0.16) \times 10^{3}$ cells $/ \mu \mathrm{l}(p<0.001)$ on Day 3 and $(2.92 \pm 0.26) \times 10^{3}$ cells $/ \mu l(p<$ 0.05 ) on Day 15 . However, there were no significant differences between neutrophil levels when the extract was administered alone and when it was combined with MP on 
Days 3 and 9. Similarly, Ip50 induced a significant increase of neutrophils count from Days 3 to 21 with a high peak at Day15 (3.01 to 0.77$) \times 10^{3}$ cells $/ \mu \mathrm{l}(p<0.001)$ despite the presence of MP15 (see Fig 2).

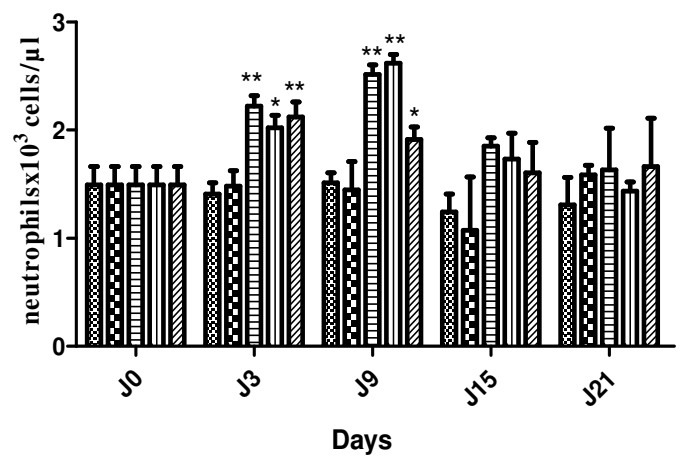

Figure 1: Variation of the neutrophils count with time following administration of Erigeron floribundus

Key: $=\mathrm{NaCl} 0.9 \% ; \quad=\mathrm{Ef} 25 \mathrm{mg} / \mathrm{kg} \mathrm{BW}$ (Ef25);

|l| $=E f$ 50mg/kg BW (Ef50); 目 = Ef 75mg/kg BW (Ef75);

Ef $=100 \mathrm{mg} / \mathrm{kg} \mathrm{BW}(\mathrm{Ef100}){ }^{*} p<0.05 ;{ }^{* *} p<0.001$.

Effect of combined extract and methylprednisolone/isoprinosine on neutrophil count

Figure 2 shows that while methylprednisolone (MP, $15 \mathrm{mg} / \mathrm{kg}$ ) alone had no effect on the count of neutrophils, combining it with the extract increased neutrophil count to as high as $(3.02 \pm 0.27) \times 10^{3}$ cells $/ \mu l(p<0.001)$ on Day $9,(2.50 \pm 0.16) \times 10^{3}$ cells $/ \mu \mathrm{l}(p<0.001)$ on Day 3 and $(2.92 \pm 0.26) \times 10^{3}$ cells $/ \mu \mathrm{l}(p<$ 0.05 ) on Day 15. However, there were no significant differences between neutrophil levels when the extract was administered alone and when it was combined with MP on Days 3 and 9. Similarly, Ip50 induced a significant increase of neutrophils count from Days 3 to 21 with a high peak at Day15 (3.01 to 0.77$) \times 10^{3}$ cells $/ \mu \mathrm{l}(p<0.001)$ despite the presence of MP15 (see Fig 2).

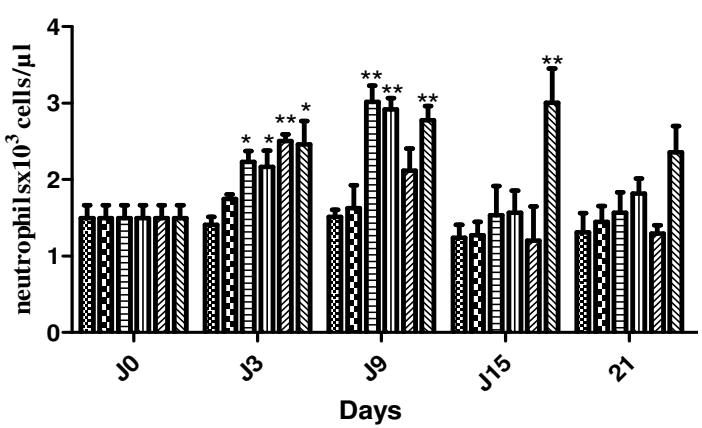

Figure 2: Variation of the neutrophils count by Ef and Ip on neutrophil count following administration of methylprednisolone (MP)

Key: $\quad \mathrm{NaCl} 0.9 \% ; 0=\mathrm{MP} 15$; 目 $=\mathrm{MP} 15+\mathrm{Ef50} ;=\mathrm{MP} 15+\mathrm{Ef75}$

$\mathbb{Z}=\mathrm{MP} 15+\mathrm{Ef} 100 ; \quad$ 四MP15 + Ip50; ${ }^{*} p<$

$0.05 ;{ }^{* *} p<0.001$.

\section{Effect of extract on lymphocyte count}

Figure 3 illustrates that the extract induced a significant increase in total lymphocyte count on Day 3 from $1753 \pm 64$ to $2056 \pm 81 \mathrm{cells} / \mu \mathrm{l}$ $(p<0.0001)$ for Ef75, to $1958 \pm 54$ cells $/ \mu l(p$

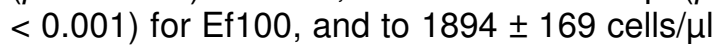
$(p<0.05)$ for Ef50. These increases were reversed by Day 21 .

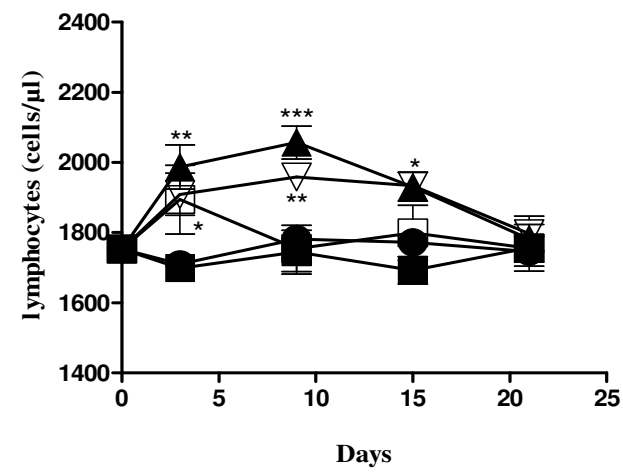

Figure 3: Effect of Erigeron floribundus extract on total lymphocytes count

Key: • = Control $(0.9 \% \mathrm{NaCl}) ; \mathbf{u}=\mathrm{Ef} 25 \mathrm{mg} / \mathrm{kg}(\mathrm{Ef25}) ; \square$ $=\mathrm{Ef} 50 \mathrm{mg} / \mathrm{kg}(\mathrm{Ef50}) ; \boldsymbol{\Delta}=\mathrm{Ef} 75 \mathrm{mg} / \mathrm{kg}(\mathrm{Ef75}) ; \nabla=\mathrm{Ef}$ $100 \mathrm{mg} / \mathrm{kg}($ Ef100); $\mathrm{n}=6) ;{ }^{*} p<0.05,{ }^{* *} p<0.001$ and ${ }^{* * *} p$ $<0.0001$. 


\section{Effect of Ef/MP mixture on total lympho- cyte count}

Figure 4 shows that while MP15 produced a significant decrease $(p<0.0001)$ in the level of total lymphocytes from $2715 \pm 88$ to 2250 \pm 132 cells $/ \mu$ l (Day 3) and to $2313 \pm 65.06$

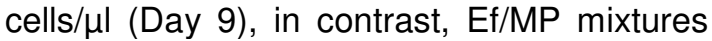
induced a significant increase in total lymphocytes.

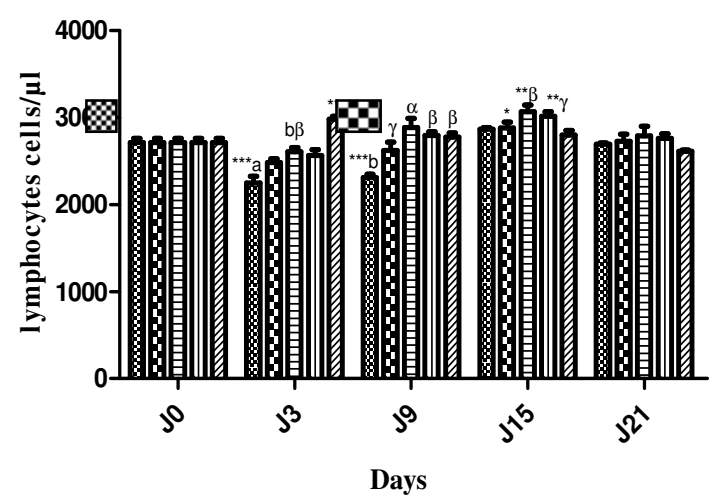

Figure 4: Effect of Ef and Ip on total lymphocytes following the administration of MP.

Key: = NaCl $0.9 \% ; \quad=$ Ef $25 \mathrm{mg} / \mathrm{kg}$ BW $(E f 25) ;$ 四 = Ef 50mg/kg BW (Ef50); 园 = Ef $75 \mathrm{mg} / \mathrm{kg}$ BW (Ef75); $\mathbb{Z}==$ Ef $100 \mathrm{mg} / \mathrm{kg} \mathrm{BW}$ (Ef100)

${ }^{*} p<0.05,{ }^{* *} p<0.001$ and ${ }^{* * *} p<0.0001$.

The significant difference between the average count of total lymphocytes induced by the mixtures of Mp15+lp50; Mp15+Pb50, $\mathrm{Pb} 75$ or $\mathrm{Pb} 100$ is expressed by $a(p<$ $0.0001) ; b \quad(p<0.001 ; c \quad(\mathrm{p}<0.05)$. The significant difference between the average level of total lymphocytes induced by MP15 and mixtures MP15+Ef50, Ef75 or Ef100 is expressed by $\alpha(p<0.0001)$; $\beta(p<0.001$; and $\mathrm{Y}(p<0.05$

\section{Effect of Ef on TCD4+ count}

Increasing doses of the extract (Ef) $\geq$ $50 \mathrm{mg} / \mathrm{kg}$ induced a significant increase in total blood TCD4+ from Day 3 to 15, as Fig. 5 shows, with Ef50 and Ef100 producing $146 \pm$ 6 cells $/ \mu \mathrm{l}(p<0.05)$ and $157 \pm 4$ cells $/ \mu \mathrm{l}(p<$ 0.001 ), respectively, on Day 3 , compared to $128 \pm 5$ cells/ $\mu \mathrm{l}$ on Day 0. The peak for Ef75
$(157 \pm 2$ cells $/ \mu \mathrm{l}, p<0.001)$ was reached on Day 9 .

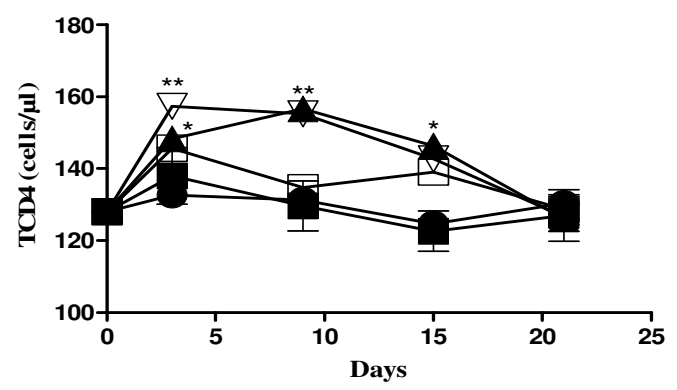

Figure 5: Effect of Erigeron floribundusextract on TCD4+ count

Key: • = Control $(0.9 \% \mathrm{NaCl}) ; \boldsymbol{a}=\mathrm{Ef} 25 \mathrm{mg} / \mathrm{kg}(\mathrm{Ef} 25) ; \square$ $=\mathrm{Ef} 50 \mathrm{mg} / \mathrm{kg}(\mathrm{Ef50}) ; \boldsymbol{\Delta}=\mathrm{Ef} 75 \mathrm{mg} / \mathrm{kg}(\mathrm{Ef75}) ; \nabla=\mathrm{Ef}$ $100 \mathrm{mg} / \mathrm{kg}(\mathrm{Ef100}) ; \mathrm{n}=6)$

\section{Effect of Ef/MP mixture on TCD4+ count}

Figure 6 shows that MP15 induced a significant decrease in CD4+ count on Day 3 from $125 \pm 3$ to $106 \pm 4$ cells $/ \mu \mathrm{l}(p<0.001)$ and on Day 9 from $125 \pm 3$ to $112 \pm 5$ cells $/ \mu$ l $(p<0.05)$. In contrast, Ef/MP mixtures increased significantly $(p<0.001, p<0.0001)$ the level of CD4+ count. Ip50/MP15 mixture increased significantly $(p<0.05)$ TCD4+ count on Day $3(125 \pm 3$ to $140 \pm 5$ cells/ $\mu$ l).

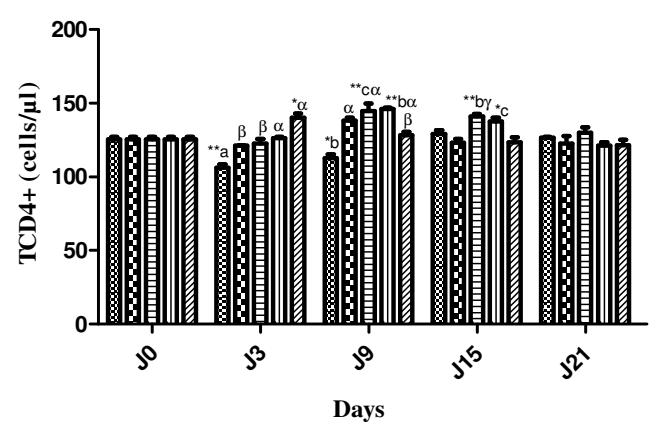

Figure 6: Effect of Erigeron floribundus extract on TCD4+ count folowing administration of MP

Key: $\quad \otimes=\mathrm{NaCl} 0.9 \%$; $=$ Ef $25 \mathrm{mg} / \mathrm{kg}$ $\mathrm{BW}(\mathrm{Ef25}) ;$ [ = Ef $50 \mathrm{mg} / \mathrm{kg}$ BW (Ef50;) $\mathbb{Z}^{\prime}=\mathrm{Ef} 75 \mathrm{mg} / \mathrm{kg} \mathrm{BW}(\mathrm{Ef75}) ; \quad$ 目 $=\mathrm{Ef}$ $100 \mathrm{mg} / \mathrm{kg} \mathrm{BW}$ (Ef100) 
The levels of significance difference are expressed by: ${ }^{*} p<0.05$ and ${ }^{* *} p<0.001$. The significant difference between the average count of total lymphocytes induced by the mixtures of Mp15+lp50; Mp15+Pb50, Pb75 or $\mathrm{Pb} 100$ is expressed by $a(p<0.0001) ; b(p<$ 0.001 ; $\mathrm{c}:(\mathrm{p}<0.05)$. The significant difference between the average level of total lymphocytes induced by MP15 and mixtures MP15+Ef50, Ef75 or Ef100 is expressed by a $(p<0.0001) ; \beta(p<0.001)$; and $\mathrm{Y}(p<0.05)$

\section{DISCUSSION}

This work has shown that the total aqueous extract of the leaves of Erigeron floridundus (Asteraceae) (Ef) increased the levels of total lymphocytes, neutrophils and TCD4+. Indeed, in addition to their role in inflammation via the activation of NK cells, neutrophils also play a crucial role in the immune system with regard to innate and acquired immunity [12]. Therefore, increasing their levels in peripheral blood would strengthen the immune system. In this regard, therefore, Erigeron floribundus stimulates the production of these cellular markers of immunity in circulating blood. The increase in total lymphocyte and neutrophil levels might have resulted either from the release of immune cells from their sequestration sites in lymphatic tissue, or following their synthesis in the bone marrow [13] due to stimulation by Ef. On the other hand, methylprednisolone induced a decrease in total lymphocyte and CD4+. According to Wong et al [14], glucocorticoids can suppress cell-mediated immunity by inhibiting the production of lymphocyte mediator or via reduction in the cell response targets of these mediators.

The comparable effects of Ef and isoprinosine (Ip) on the immunosuppressive activity of MP has shown that the products are inhibitors of the immunosuppressive action of MP either on the synthesis sites or the site reservoirs of lymphocytes and CD4+. Thus, Ef would have stimulated the release of lymphocytes and CD4+ in the bloodstream as indicated by Cillari et al [15] with regard to the immune-potentiating effect of isoprinosine in protecting persons infected with HIV. Furthermore, it has been demonstrated that treatment of 43 children with respiratory infection with isoprinosine $50 \mathrm{mg} / \mathrm{kg} /$ day three times a week for six months, resulted in an increase in the number of lymphocytes TCD3+, TCD4+ and TCD8+ [11]. Also, administration of $50 \mathrm{mg} / \mathrm{kg}$ isoprinosine to mice was reported to lead to a proliferation of normal $T$ cells [16]. This isoprinosine-like effect of Ef suggests that the extract could increase the level of CD4+ T lymphocytes in immunocompromised persons.

In contrast, $15 \mathrm{mg} / \mathrm{kg}$ dose of MP had no effect on neutrophils, because according to Weiner et al [17], only high doses of intravascular MP $(30 \mathrm{mg} / \mathrm{kg})$ are capable of inducing neutropenia. Therefore, the inhibitory effect on cellular immunity by MP at this dose $(15 \mathrm{mg} / \mathrm{kg})$ would be lymphocytic, not neutrocytic. The rate of increase of lymphocytes in the presence of MP by Ip was significantly higher $(p<0.0001)$ than that induced by Ef on Day 3, when administered at the same concentration level $(50 \mathrm{mg} / \mathrm{kg}$ ), probably because isoprinosine is a purified product compared to the aqueous extract of Ef. According to Hadden and Wybran [18], isoprinosine is an antiviral agent that stimulates the immune cells. Thus, this immunopotentiating property of Ip should make it useful for the treatment of autoimmune diseases [17]. Having regard to the isoprinosine-like effect of Ef on immune cells, one might suggest that this effect could also have immunopotentiating activity on immune cells, namely, neutrophils and total lymphocytes.

\section{CONCLUSION}

This study showed that the aqueous leaf extract of Erigeron floribundus (Ef) has a stimulating effect on the blood levels of some cellular markers of immunity, including neutrophil cells, total lymphocytes and TCD4+ cells. The extract inhibited the 
immunodeficiency created with methylprednisolone. The extract could, thus, be useful in developing therapies for immunodeficiency diseases.

\section{ACKNOWLEDGEMENT}

The authors wish to express their gratitude to Pr Laurent Ake-Assi of the Department of Botany, University of Cocody Abidjan, for the botanical identification and collection of the plant. We also thank the technicians of the immunology and hematology laboratory of C.H.U of Yopougon-Abidjan (Côte d'Ivoire) for their assistance.

\section{REFERENCES}

1. Scott NM, Vijay KV, Sang-Jun H, Erin EW, Mary EK, Glickman JN, Sharpe AH, Ahmed R. PD$L 1$ has distinct functions in hematopoietic and nonhematopoietic cells in regulating $T$ cell responses during chronic infection in mice $J$ Clin Invest. 2010; 120(7): 2508-2515.

2. van Bergen J, Kooy-Winkelaar EMC, van Dongen $H$, van Gaalen $F A$, Thompson $A$, HuizingaTWJ., Feltkamp MCW, Toes REM and Koning F. Functional Killer Ig-Like Receptors on Human Memory CD4 ${ }^{+} \mathrm{T}$ Cells Specific for Cytomegalovirus. J Immunol, 2009; 182: 4175-4182.

3. Pujari S, Srasuebkul P, Sungkanuparph S, Lim PL, Kumarasamy N, Chuah J, Kumar RN, Chen $Y$ MA, Oka S, Choi JY, Lee M, Phanuphak $P$, Kamarulzaman A, Lee C, Fujie Z, Ditangco $R$, Saphonn V, Sirisanthana T, Merati TP, Smith J, Law MI. Patient Characteristics and Treatment Outcome Associated with Protease Inhibitor (Pl) use in the Asia-Pacific Region. $J$ Antivir Antiretrovir, 2009; 1(1): 28-35.

4. Raychaudhuri SK, Raychaudhuri SP. Scid mouse model of Psoriasis: a unique tool for drug development of autoreactive T-cell and Th-17 cell-mediated autoimmune deseases. Indian $\mathrm{J}$ Dermatol, 2010; 55(2): 157-160

5. Frey FJ. Immunosuppressive drugs--useful confusion of the 20th century? Ther Umsch. 1999; 56(12): 708-712.

6. Cohn LA. Glucocorticosteroids as immunosuppressive agents. Semin Vet Med Surg (Small Anim). 1997;12(3):150-156.
7. de Pádua CAM, César CC, Bonolo PF, Acurcio FA, Guimarães MDC. Self-Reported Adverse Reactions Among Patients Initiating Antiretroviral Therapy in Brazil. Braz J Infect. Dis, 2007; 11(1): 20-26.

8. Asongalem EA, Foyet HS, Ngogang J, Folefoc GN, Dimo $T$, Kamtchouing P.Analgesic and antiinflammatory activities $f$ Erigeron floribundus. J Ethnopharmacol, 2004; 91(2-3): 301-308.

9. Tra Bi FH, Kouame NF, Favel A, Fallague $K$. Activité antifongique de quelques plantes de la flore ivoirienne. Sciences \& Nature 2007; 4 (2): 117-122.

10. Mitjans M, Garcia L, Marrero E, Vinardell MP. Study of ligmed- $A$, an antidiarrheal drug based on liguin, on rat small intestine enzyme activity and morphometry; $J$ Vet Pharmacol Ther, 2008; 24: 349-351.

11. Litzman J, Lokaj J, Krejcí M, Pesák S, Morgan G. Isoprinosine does not protect against frequent respiratory tract infections in childhood. Eur $J$ Pediatr, 1999; 158(1):32-7.

12. Costantini $C$, Cassatella MA. The defensive alliance between neutrophils and NK cells as a novel arm of innate immunity. J Leukoc Biol, 2010; 89: 1-13.

13. Moreau-Gachelin F. Le régulateur transcriptionnel Spi-1/PU. 1 est un facteur determinant dans la differentiation des lymphocytes $B$ et des macrophages. Hematol, 1999; 3(2):195-196.

14. Wong LG, Colburn KK, Kacena A, Weisbart RH. Effect of methylprednisolone on the production of neutrophil migration inhibition factor by $T$ lymphocytes (NIF-T). Immunopharmacol, 1981; 3(2): 179-185

15. Cillari E, Dieli M, Campo PLO, Sireci G, Caffarelli $A$, Maltese $E$, Millott $S$, Milano $S$, Liew FY. Protective effect of isoprinosine in genetically susceptible $B A L B / c$ mice infected with Leishmania major. Immunol, 1991; 74: 25-30

16. Fischbach $M$, Talal $N$. Ability of Isoprinosine to restore interleukin-2 production and $T$ cell proliferation in autoimmune mice. Clin. Exp. Immunol, 1985; 61: 242-247.

17. Wiener $S L$, Wiener $R$, Urivetzky $M$, Shafer $S$, Isenberg $H D$, Janov $C$, Meilman $E$. The Mechanism of Action of a Single Dose of Methylprednisolone on Acute Inflammation In Vivo. J Clin Invest, 1975; 56: 679-689.

18. Hadden JW, Wybran J. Immunopotentiators.II. Isoprinosine, NPT 15392: modulators oflymphocyte and macrophage development and function. Adv. Immunopharmacol. 1981; 1: 457 